\title{
Detection of the oyster herpesvirus in commercial bivalves in northern California, USA: conventional and quantitative PCR
}

\author{
Colleen A. Burge ${ }^{*}$, Robyn E. Strenge ${ }^{*}$, Carolyn S. Friedman ${ }^{* *}$ \\ School of Aquatic and Fishery Sciences, University of Washington, Box 355020, Seattle, Washington 98195, USA
}

\begin{abstract}
The ostreid herpesvirus (OsHV-1) and related oyster herpesviruses (OsHV) are associated with world-wide mortalities of larval and juvenile bivalves. To quantify OsHV viral loads in mollusc tissues, we developed a SYBR ${ }^{\circledR}$ Green quantitative PCR (qPCR) based on the A-region of the OsHV-1 genome. Reaction efficiency and precision were demonstrated using a plasmid standard curve. The analytical sensitivity is 1 copy per reaction. We collected Crassostrea gigas, C. sikamea, C. virginica, Ostrea edulis, O. lurida, Mytilus galloprovincialis, and Venerupis phillipinarum from Tomales Bay (TB), and C. gigas from Drakes Estero (DE), California, USA, and initially used conventional PCR (CPCR) to test for presence of OsHV DNA. Subsequently, viral loads were quantified in selected samples of all tested bivalves except $O$. lurida. Copy numbers were low in each species tested but were significantly greater in $C$. gigas $(\mathrm{p}<0.0001)$ compared to all other species, suggesting a higher level of infection. OsHV DNA was detected with CPCR and/or qPCR and confirmed by sequencing in C. gigas, C. sikamea, C. virginica, O. edulis, M. galloprovincialis, and V. phillipinarum from TB and C. gigas from DE. These data indicate that multiple bivalve species may act as reservoirs for OsHV in TB. A lack of histological abnormalities in potential reservoirs requires alternative methods for their identification. Further investigation is needed to determine the host-parasite relationship for each potential reservoir, including characterization of viral loads and their relationship with infection (via in situ hybridization), assessments of mortality, and host responses.
\end{abstract}

KEY WORDS: Oyster herpesvirus · Tomales Bay · Drakes Estero · California · Quantitative polymerase chain reaction

\section{INTRODUCTION}

Herpesviruses infecting marine invertebrates often cause disease in multiple host genera and or species. Intensive aquaculture, where many species of marine invertebrates are cultured in close proximity to one another, may promote viral transmission to a potential new host species (Arzul et al. 2001b). The first characterized herpesvirus that infects marine invertebrates, the ostreid herpesvirus-1 (OsHV-1), was purified, described, and fully sequenced from oyster larvae in France (Davison et al. 2005). In recent years OsHV-1 and other herpes-like viruses have been discovered in bivalve hosts on a global scale (e.g. Friedman et al. 2005, Moss et al. 2007). However, the genetic and taxonomic relationships among oyster herpesviruses and their relationship to fully characterized members of the Herpesvirales remain largely unknown. As multiple strains of OsHV-1 may exist, we will use OsHV (oyster herpesvirus) to broadly describe herpesvirus(es) infecting bivalve molluscs. OsHV infects members of several bivalve genera including the Pacific oyster Crassostrea gigas (Nicolas et al. 1992, Renault et al. 2000a), the European flat oyster Ostrea edulis (Renault et al. 2000a, da Silva et al. 2008), the Manila clam Venerupis (= Ruditapes, Tapes) philippinarum, (Arzul et al. 2001b), and 
the French scallop Pecten maximus (Arzul et al. 2001a). OsHV has been associated with mortalities among bivalve larvae and/or seed in France, New Zealand, Spain, and California, USA (Hine et al. 1992, Nicolas et al. 1992, Renault et al. 2000a, Friedman et al. 2005, Burge et al. 2006, da Silva et al. 2008). In California, severe mortalities first occurred in Tomales Bay (TB) in 1993 (Cherr \& Friedman 1998), when Pacific oyster seed losses reached up to $90 \%$. These losses have been termed summer seed mortality (SSM) to distinguish this phenomenon from summer mortality of adult Pacific oysters (Burge et al. 2006). An association between OsHV and SSM was demonstrated in 2 field studies in 2000-2001 and 2003 (Burge et al. 2006, 2007). Although differential mortality was documented in stocks of Pacific oysters in TB in 2003, OsHV prevalence based on conventional polymerase chain reaction (CPCR) assays (primer pairs A3/A4 and A5/A6 nested CPCR assays) was similar among stocks and thus could not explain observed differences in losses. Although sensitive, the qualitative nature (presence/absence) of $\mathrm{cPCR}$ data limits its application to determining target prevalence and cannot provide information on viral load or intensity. In contrast, quantitative PCR (qPCR) is also a sensitive assay but additionally quantifies the target (copy number of target DNA sequence). OsHV-1 specific semi-quantitative PCR (Renault et al. 2004) and qPCR (Pepin et al. 2008) assays were developed based on the C-region of OsHV-1, a region represented twice in the OsHV-1 genome.

OsHV infects multiple bivalve species, including life stages that are refractory to pathology and mortality; viral infections may be latent and subsequently may be stimulated by adverse conditions to become active infections. Thus, increased detection sensitivity and quantification of virus abundance are particularly useful in studying herpesviruses. The activation or reactivation of OsHV replication in local hosts and dissemination to naïve individuals is hypothesized to drive OsHV transmission in TB, where uninfected juvenile Pacific oyster seed that are planted each year die of SSM (Cherr \& Friedman 1998, Friedman et al. 2005, Burge et al. 2006, 2007). Although Pacific oysters in TB have experienced SSM annually since 1993, members of other bivalve species reared in close proximity to dying Pacific oysters appear to be unaffected. However, only losses of Pacific oysters have been quantified, and the other species of bivalves in TB have not been tested for OsHV.

Given that multiple bivalve species are potential hosts of low level virus infections, we developed an OsHV-specific qPCR based on the A-region of the OsHV-1 genome to detect and quantify this virus in multiple possible hosts reared in TB, California. The Aregion of the OsHV-1 genome was specifically chosen for development of the qPCR as sequence data is available only for this region of the OsHV-1 genome detected in Pacific oysters in California (Friedman et al. 2005). Additionally, Friedman et al. (2005) were unable to amplify the C-region of the OsHV-1 genome using the $\mathrm{C} 2 / \mathrm{C} 6$ primers, which suggested nucleotide variability in this region. In the present study, we tested a subset of samples from 6 bivalve species that had been previously tested with an OsHV-specific nested cPCR. Initial cPCR testing included tissues collected during August-October 2003 from members of 7 bivalve species including Pacific oysters and 6 species that were reared in close proximity to dying Pacific oysters in TB, California. In addition, we examined Pacific oysters from nearby Drakes Estero (DE). In the qPCR assays, we tested only samples collected during August or September 2003 from TB. We used PCR as a proxy for infection since viral lesions are not typically microscopically visible in post metamorphic bivalves (Friedman et al. 2005, Burge et al. 2006), and viruses can be difficult to detect with histology when present at low levels (Batista et al. 2007).

\section{MATERIALS AND METHODS}

OsHV-specific qPCR development. OsHV specific qPCR primer design, conditions, and analyses: Prospective primers were designed based on the A-region of the OsHV-1 genome sequenced from OsHV found in Tomales Bay, California (GenBank AY459364), using Primer Express software (PE Applied Biosystems). A single copy of the A-region is present in each viral genome (Batista et al. 2007). The forward and reverse primer sequences chosen were: qPCR AF (5'-TCG TTC AAT CTT ACA ATT AAC ATC TGT ATG A-3') and qPCR AR (5'-AGT TTA AGG TTA TAA TGG AAT TGG AGA ACC T-3'), which amplify a $151 \mathrm{bp}$ fragment. Reactions $(25 \mu \mathrm{l})$ were performed in 96-well microplates containing $12.5 \mu \mathrm{l}$ SensiMix ${ }^{\mathrm{TM}}$ deoxy uracil (Quantace), $15 \mu \mathrm{g}$ of BSA, 0.5 units of Uracil DNA Glycosylase (UNG) (Quantace), $2 \mu \mathrm{l}$ of genomic or plasmid DNA and $1 \times \mathrm{SYBR}^{\circledR}{ }^{\circledR}$ Green I solution (Quantace). A primer matrix (50 to $600 \mathrm{nM}$ ) was used to determine the optimal primer concentration; $300 \mathrm{nM}$ for both primers was chosen, based on a low cycle threshold (CT)-value and reduced primer concentration (Stratagene). All qPCR reactions were carried out using a MX3000 qPCR instrument (Stratagene) and the following reaction conditions: $37^{\circ} \mathrm{C}$ for $10 \mathrm{~min}$ (UNG incubation step), $60^{\circ} \mathrm{C}$ for 2 min (UNG inactivation step), $95^{\circ} \mathrm{C}$ for $10 \mathrm{~min}$ (polymerase activation); followed by 40 cycles of $95^{\circ} \mathrm{C}$ for $15 \mathrm{~s}, 60^{\circ} \mathrm{C}$ for $1 \mathrm{~min}$, and $72^{\circ} \mathrm{C}$ for $30 \mathrm{~s}$. Following the amplification of sample templates, a melt curve analysis $\left(95^{\circ} \mathrm{C}\right.$ for $1 \mathrm{~min}, 55$ to $95^{\circ} \mathrm{C}$ incremented stepwise by 
$5^{\circ} \mathrm{C}$ per $30 \mathrm{~s}$ ) was used to confirm amplification of a single product. qPCR data were analyzed with the Stratagene MXPro QPCR software (version 4.01). Initially, we used an amplification-based threshold algorithm to set the threshold for CT-value determination, but for precise comparisons between runs we maintained the baseline at $500 \mathrm{dR}$ (fluorescence units measured).

Construction of a qPCR standard curve: The OsHV standard curve was constructed by first cloning a $151 \mathrm{bp}$ fragment amplified with primers qPCR AF and qPCR AR into the TOPA TA vector (Invitrogen). The product obtained was sequenced to confirm identity. Three aliquots of supercoiled plasmid were purified using a QIAprep Spin Miniprep kit (Qiagen), and linearized using the NOTI enzyme (New England Biolabs) at $10 \times$ concentration to obtain single cuts in each plasmid, which were verified by gel electrophoresis. The concentration of linearized plasmid was determined with a Quant-IT ${ }^{\mathrm{TM}}$ PicoGreen ${ }^{\circledR}$ dsDNA Assay kit (Molecular Probes) with fluorescence intensity (486 nm excitation, $535 \mathrm{~nm}$ emission) measured using a Genios Plate Reader (Tecan) and Magallan 5.3 software. The $4104 \mathrm{bp}$ plasmid containing our target OsHV gene has a mass of $4.498 \times 10^{-18} \mathrm{~g}$ per plasmid (or copy). Using the mass of a single plasmid, we estimated that $1.359 \times$ $10^{-10} \mathrm{~g}$ of linearized plasmid equaled 30 million copies. The plasmid was diluted in Tris-EDTA (TE) to yield $3.0 \times 10^{7}$ copies; 10 -fold serial dilutions in TE were used as PCR templates to generate a standard curve.

qPCR efficiency and precision: To determine $\mathrm{qPCR}$ efficiency and precision, 3 separate plasmid dilution series containing 3 to 3 million copies were made as described above and run in triplicate on 3 different plates. The coefficients of determination were calculated using CT-values among plasmid curves and runs. The coefficient of variation was calculated among replicate samples in each run. Efficiency $(E)$ is calculated from the slope of the standard curve according to the following formula: $E=10^{(-1 / \text { slope })}$. Ideally the efficiency should be $100 \%$, meaning that for each cycle the amount of product doubles. We aimed for an efficiency of between 90 and $110 \%$.

Analytical sensitivity and specificity: Analytical sensitivity, considered to be $50 \%$ amplification of the target (Wright \& Jacobson 2009), was determined by running sets of standards that included 1, 3, and 10 plasmid copies per reaction, 24 times on 3 separate plates. Analytical specificity was determined by testing samples from 3 aquatic herpesviruses provided by Dr. R. P. Hedrick (University of California, Davis, California, USA): Koi herpesvirus (CyHV3), catfish herpesvirus (ICHV1), and sturgeon herpesvirus (ACiHV2), and known OsHV-1 negative Pacific oyster DNA collected from Washington State oysters, where OsHV has not been documented.
qPCR inhibition: DNA from gill and mantle tissues of uninfected juvenile Pacific oysters and Manila clams, which may contain PCR inhibitors, were added to qPCR reactions at specific DNA concentrations per reaction $(0,20,60$, and $140 \mathrm{ng})$ to test for inhibition. The coefficients of determination were calculated for CT-values obtained in each oyster or clam DNAspiked curve and a non-spiked curve. The coefficient of variation was also calculated among triplicate replicates at each concentration.

Bivalves. Commercially cultured oysters (Pacific oyster, European flat oyster, Kumamoto oyster C. sikamea, and eastern oyster $C$. virginica), and Manila clams were collected from lease M340-11 in TB on August 27, 2003 (Fig. 1, Table 1), Mediterranean mussels Mytilus galloprovincialis were collected on September 24, 2003; Olympia oysters O. lurida and additional groups of eastern and Kumamoto oysters and Manila clams were collected on October 2, 2003. All species collected in TB were produced originally from hatcheries in Washington and/or Oregon, USA except Mediterranean mussels and Olympia oysters, which reproduce naturally in the bay. Pacific oysters from fall 2002 and spring 2003 outplants were also collected from Schooner Bay, DE on August 27, 2003. Pacific oysters collected from DE originated as larvae from hatcheries

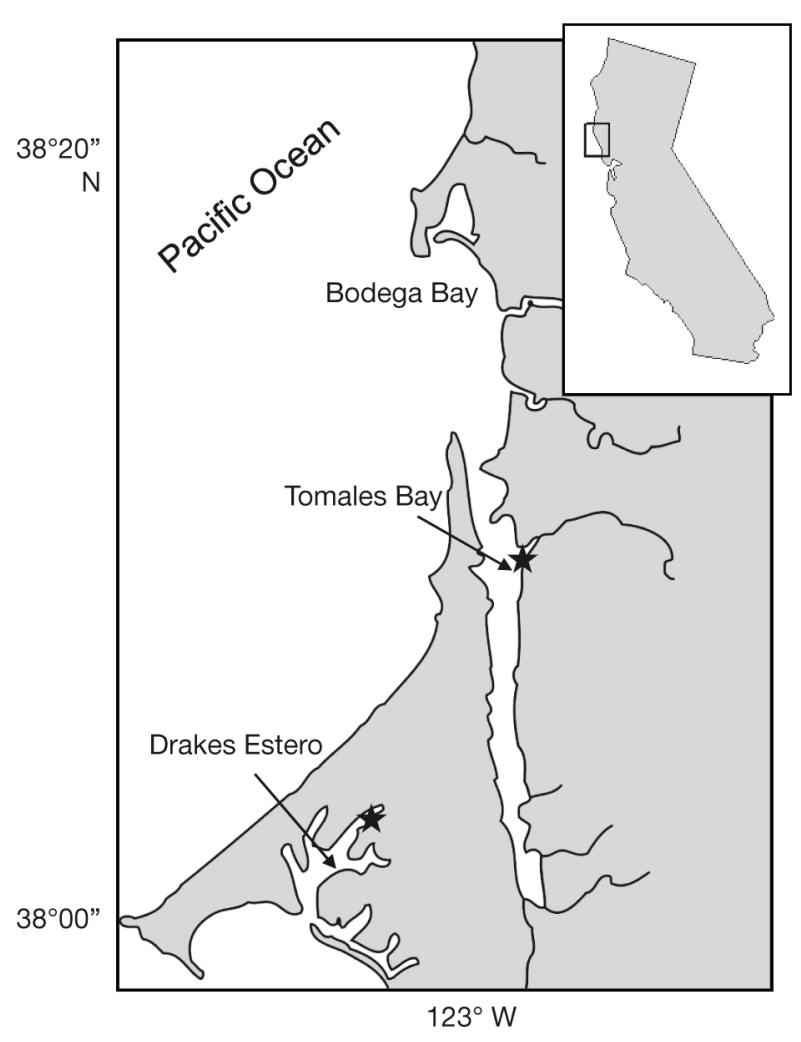

Fig. 1. Location of study areas Tomales Bay and Drakes Estero in California, western USA (insert). Stars: collection sites 
Table 1. Sample information for bivalves collected in Tomales Bay and Drakes Estero (DE), California, USA

\begin{tabular}{|c|c|c|c|c|c|c|}
\hline Date collected & Common name & Latin name & $\begin{array}{l}\text { Number } \\
\text { collected }\end{array}$ & $\begin{array}{c}\text { Height } \\
(\mathrm{cm}) \pm 1 \mathrm{SE}\end{array}$ & $\begin{array}{l}\text { Height } \\
\text { range }\end{array}$ & $\begin{array}{l}\text { Dead or } \\
\text { moribund }\end{array}$ \\
\hline \multirow[t]{7}{*}{ August 27, 2003} & Pacific oyster & Crassostrea gigas & 54 & $4.8 \pm 0.2$ & $2.9-7.7$ & 1 \\
\hline & Pacific oyster (DE) Fall & C. gigas & 36 & $3.1 \pm 0.1$ & $2.0-5.2$ & 0 \\
\hline & Pacific oyster (DE) Spring & C. gigas & 0 & & & All dead \\
\hline & Flat oyster & Ostrea edulis & 14 & $6.5 \pm 0.1$ & $5.6-7.2$ & 42 \\
\hline & Kumamoto oyster & C. sikamea & 42 & $4.4 \pm 0.1$ & $2.7-5.8$ & 0 \\
\hline & Eastern oyster & C. virginica & 50 & $5.0 \pm 0.1$ & $3.2-7.1$ & 0 \\
\hline & Manila clam & Venerupis philippinarum & 26 & $2.5 \pm 0.04$ & $1.9-3.0$ & 21 \\
\hline September 24, 2003 & Mediterranean mussel & Mytilus galloprovincialis & 60 & $5.1 \pm 0.2$ & $1.9-8.2$ & 0 \\
\hline \multirow[t]{4}{*}{ October 2, 2003} & Olympia oyster & O. lurida & 60 & $3.4 \pm 0.07$ & $2.1-5.0$ & 8 \\
\hline & Kumamoto oyster & C. sikamea & 11 & $4.6 \pm 0.2$ & $3.6-6.2$ & 0 \\
\hline & Eastern oyster & C. virginica & 10 & $7.4 \pm 0.5$ & $5.5-9.7$ & 0 \\
\hline & Manila clam & V. philippinarum & 12 & $3.1 \pm 0.2$ & $2.1-5.0$ & 0 \\
\hline
\end{tabular}

in Washington and/or Oregon were set on site. The initial collection date was chosen as OsHV presence in Pacific oysters (coupled with mortality) was noted midAugust at the nearby Outer Bay site in TB (Burge et al. 2006). All animals were shipped live on ice, overnight to the University of Washington. Upon arrival, live and dead counts were performed, and the shell height of each oyster and the maximum valve dimensions of clams and mussels were measured to the nearest $0.1 \mathrm{~mm}$ prior to tissue sampling (Table 1).

Nucleic acid extraction. Gill and mantle tissues from individual animals were stored separately in 95\% ethanol until DNA extraction using a QIAamp DNA Mini Kit (Qiagen) following the manufacturer's protocol. Initially, tissue samples were extracted in pools from 5 individuals. When OsHV was detected in a specific pool, tissue samples from individual bivalves were then extracted separately.

PCR. OsHV-specific CPCR methods: We followed the nested PCR protocol of Renault et al. (2000b) as modified by Friedman et al. (2005) that employed the A3/A4 and A5/A6 primer combinations. All samples were tested with $\mathrm{CPCR}$ in duplicate amplifications at both $1 \mu \mathrm{l}$ volume ( 50 ng) and $500 \mathrm{ng}$ of genomic DNA template. Products were separated on a $1 \%$ agarose gel, stained with ethidium bromide, and visualized by UV illumination.

CPCR sensitivity analysis: To determine the sensitiv-

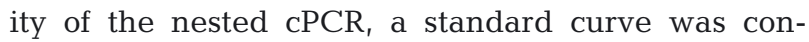
structed by first cloning a $1001 \mathrm{bp}$ fragment amplified with primers A3 and A4, into the TOPA TA vector (Invitrogen). Methods for plasmid purification, linearization, quantification, and dilution to generate a standard curve, were identical to those used with qPCR and described in 'Construction of a qPCR standard curve' above. For cPCR the 4932 bp plasmid had a mass of $5.405 \times 10^{-18} \mathrm{~g}$ per plasmid. Triplicate samples from the standard curve ( 3 to 3 million copies) were assayed to determine sensitivity in both the first (A3/A4 primers) and second round (A5/A6) of nested CPCR. Additionally, a 1-copy standard was diluted from the 3-copy dilution, and assayed in triplicate followed by an additional $60 \mathrm{cPCR}$ reactions.

OsHV-specific qPCR - sample methods: A subset of 10 to 13 samples from each species were tested for OsHV using the qPCR methods listed above (see Table 3). Briefly, each sample was tested in duplicate with $2 \mu \mathrm{l}$ of genomic DNA per reaction; triplicate standard curves were used. This group of samples included DNA from both OsHV-specific cPCR negative and positive animals; although positive samples were preferentially chosen when possible. Only bivalves collected on the first collection date (August 27, 2003) from TB, and Mediterranean mussels (September 24, 2003), were tested using qPCR. Samples were specifically chosen from the first sample date as qPCR copy numbers rapidly decline over time (C. A. Burge unpubl. data). Mediterranean mussels were also included based on cPCR results. Raw qPCR results were standardized per nanogram of total genomic DNA extracted. Standardized qPCR data exhibited departures from normality due to high levels of variation, and were logtransformed before differences among copy numbers quantified in bivalve species were assessed using an ANOVA and identified using a Tukey test (Zar 1999).

Universal small subunit (SSU) genes: The presence of amplifiable DNA was confirmed in all samples where OsHV was not detected using the SSU ribosomal RNA gene primers and reaction conditions of Le Roux et al. (1999). PCR products were separated and visualized as above.

Sequence analysis. To confirm cPCR results, selected OsHV cPCR products from each species $(n=8)$ were directly sequenced. PCR products were purified with the Qiaquick PCR Purification Kit (Qiagen). Cycle sequencing and reaction analysis were carried out at 
the University of Washington Biochemistry DNA Sequencing Facility. Purified PCR products were cycle sequenced using the BigDye Terminator v3.1 Cycle Sequencing Kit (Applied Biosystems) and the sequencing reactions were analyzed on a 3730XL highthroughout capillary DNA analyzer (Applied Biosystems). Each strand of the OsHV DNA was sequenced using forward and reverse primers to check for sequencing accuracy using the nested A5/A6 primers.

Although SYBR green qPCR provides a melt curve analysis, products from species where OsHV was not detected with $\mathrm{CPCR}$ were sequenced. Three $\mathrm{qPCR}$ products from one animal per species (Manila clam and Mediterranean mussel) were combined and purified with the Qiaquick PCR Purification Kit (Qiagen). Following purification products were cloned into the TOPO TA vector and plasmid (2 clones per cloning reaction) purified using a QIAprep Spin Miniprep kit (Qiagen). Purified plasmids were sequenced at the University of Washington's High Throughput Genomics Unit using ABI's BigDye Terminator Cycle Sequencing Kits (v3.1) to perform sequencing reactions. Sequencing reactions were analyzed using an ABI 3730XL instrument. Each strand of the OsHV DNA was sequenced using forward and reverse primers to check for sequencing accuracy using M13F/M13R primers.

Sequences were aligned using Sequencher software (Gene Codes). The BLAST algorithm (Altschul et al. 1990) was used to compare our sequences with those deposited in the National Center for Biotechnology Information (NCBI) GenBank database. Subsequent alignment with available OsHV and OsHV-1 sequences (Davison et al. 2005, Friedman et al. 2005, Moss et al. 2007) were used to confirm sequence identities.

Histology. Standard cross sections that included mantle, gills, gonad and digestive tissues were excised from all animals, fixed in invertebrate Davidson's solution (Shaw \& Battle 1957) for $24 \mathrm{~h}$, and processed for routine paraffin histology. Deparaffinized, $5 \mu \mathrm{m}$ tissue sections from selected animals ( $\mathrm{n}=5$ per species) in which OsHV had been detected by PCR, were selected and stained with hematoxylin and eosin (Luna 1968) and examined by light microscopy to characterize morphological changes within these individuals.

\section{RESULTS}

\section{OsHV-specific qPCR development}

qPCR reaction efficiency was $93.2 \pm 0.56 \%$ (mean \pm $\mathrm{SE}$ ), and precision comparison between curves based on our coefficient of determination was $0.994 \pm$
$0.00095 \%$ (Fig. 2). Primer dimers were not observed in melt curve analyses (data not included). Coefficients of determination values obtained were between 0.993 and 0.999. The CT-value coefficients averaged $1.04 \pm$ $0.131 \%$ with a range between 0.17 and 6.12 . Precision results (coefficient of determination and variation of CT-values) indicate that within- and between-run variation was not a significant source of error. The ability to detect low copy numbers ranged from $0 \%$ ( 0 out of 72 ) for the water control, $50 \%$ (36/72) for 1 copy, $95.8 \%$ (69/72) for 3 copies, and $100 \%(72 / 72)$ for 10 copies. Therefore, the analytical sensitivity of this assay is considered 1 copy.

A high analytical specificity $(100 \%)$ of our qPCR assay was established as no CT-values were obtained from non-OsHV aquatic herpesviruses or known OsHV-negative Pacific oyster DNA.

Similar CT values, standard curves, and precision (based on coefficient of determination and CT variation) were obtained from both non-spiked (no additional DNA) and spiked reactions $(20,60$, and $140 \mathrm{ng}$ genomic oyster or clam DNA) (Table 2). Thus, we did not detect any inhibition of our qPCR assay due to the presence of added juvenile oyster or Manila clam DNA (see Table 2).

\section{PCR results}

Prevalences of OsHV as determined by $\mathrm{CPCR}$ in Pacific oysters from TB and DE were similar (46.30 and $47.22 \%$, respectively), and exceeded those of $\mathrm{Ku}-$ mamoto and eastern oysters (22.64 and $11.67 \%$, respectively). European flat oysters had the highest OsHV cPCR prevalence of $78.57 \%$ (Fig. 3). Manila clams and Olympia oysters exhibited no CPCR evidence of OsHV.

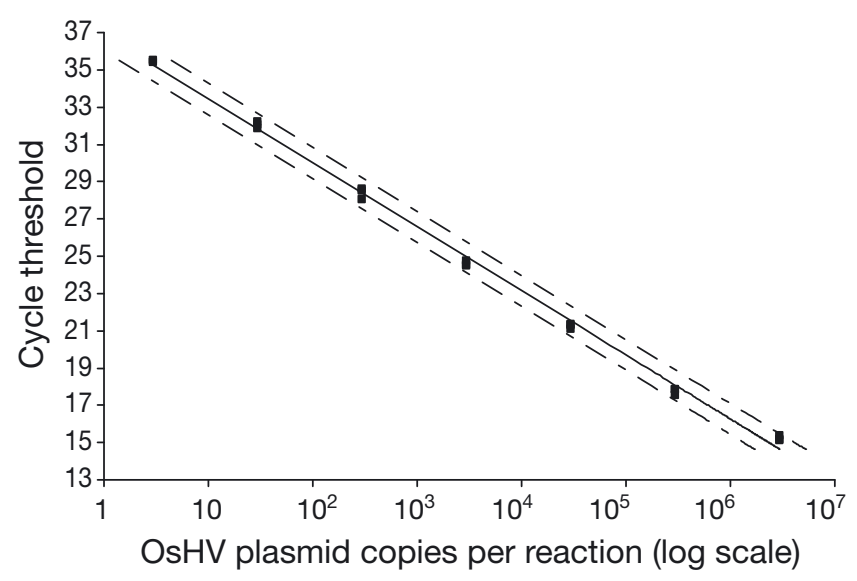

Fig. 2. OsHV standard curve showing standards ( $\mathbf{\square}$; on a log scale) from 3 to 3 million copies and 95\% confidence interval (dash-dotted line). $\mathrm{r}^{2}=0.997$ and reaction efficiency $=95.5 \%$ 
Table 2. Comparison of OsHV plasmid curves 'spiked' with DNA (20,60, and $140 \mathrm{ng}$, respectively) to non-spiked (no DNA). Reaction CD: coefficient of determination or $r^{2}$ of each qPCR standard curve. CV: mean coefficient of variation for each standard curve. CD: coefficient of determination between the non-spiked DNA (no DNA) curve and each 'spiked' curve. na: not applicable

\begin{tabular}{|lcccc|}
\hline $\begin{array}{l}\text { DNA spike } \\
\text { (ng) }\end{array}$ & $\begin{array}{c}\text { Reaction } \\
\text { efficiency }(\%)\end{array}$ & $\begin{array}{c}\text { Reaction } \\
\text { CD }\end{array}$ & $\begin{array}{c}\text { Mean } \\
\text { CV }(\%)\end{array}$ & CD \\
\hline Pacific oyster & & & & \\
0 & 100.7 & 0.996 & 0.01 & na \\
20 & 98.2 & 0.999 & 0 & 0.99 \\
60 & 97.2 & 0.996 & 0.76 & 0.99 \\
140 & 100.1 & 0.995 & 0.79 & 0.99 \\
Manila clam & & & & \\
0 & 91.2 & 0.998 & 0.52 & na \\
20 & 92.2 & 0.99 & 0.51 & 0.99 \\
60 & 91.3 & 0.998 & 0.71 & 0.99 \\
140 & 91.2 & 0.998 & 0.74 & 0.99 \\
\hline
\end{tabular}

The OsHV copy numbers per ng of genomic DNA of OsHV-qPCR positive bivalves were low for all species tested (mean $\pm \mathrm{SE}$; range): Pacific oysters (20.31 \pm $12.40 ; 0.005$ to 114.4$)$, Flat oysters $(0.098 \pm 0.29 ; 0.02$ to $0.29)$, Manila clams $(0.042 \pm 0.031 ; 0.003$ to 0.103$)$, Kumamoto oysters $(0.042 \pm 0.013 ; 0.003$ to 0.15$)$, eastern oysters $(0.094 \pm 0.068 ; 0.002$ to 0.49$)$, and Mediterranean mussels (0.0073 $\pm 0.006 ; 0.0005$ to 0.025$)$ (Fig. 4). Log-transformed data indicate Pacific oysters contained greater OsHV copy numbers per ng of tissue than all other species $(p<0.0001)$; all other species had equal copy numbers ( $p>0.05)$.

When comparing the subset of samples tested with both CPCR and qPCR, OsHV was detected in a greater number of individuals with qPCR (47:34, Table 3). However, OsHV was detected in some individuals with

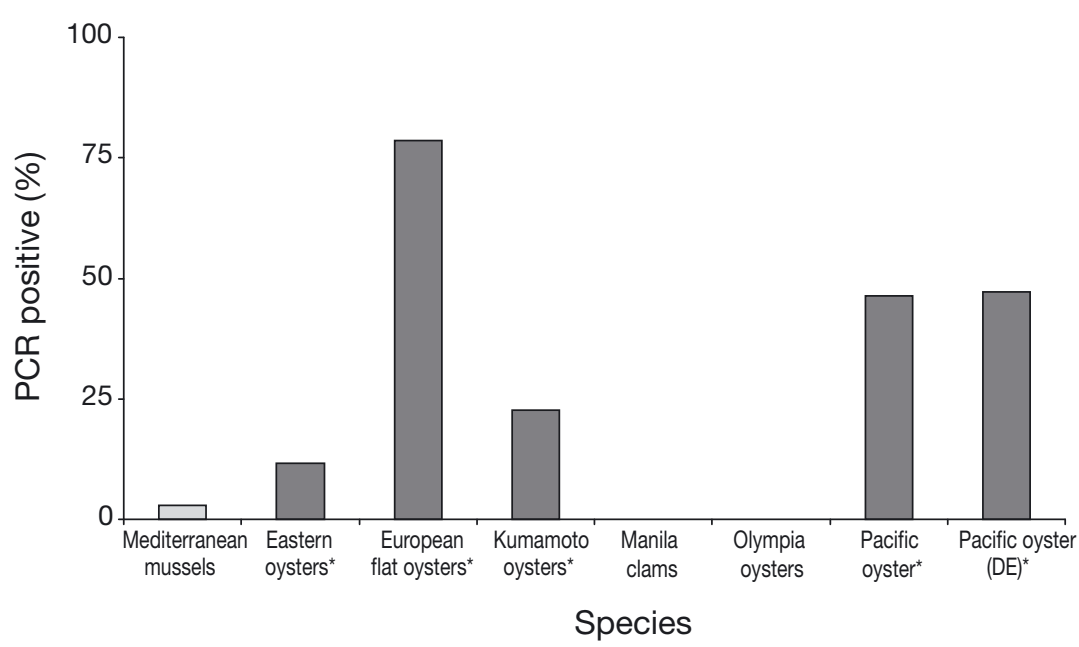

Fig. 3. cPCR OsHV prevalence in cultured bivalves (dark gray bars) collected in Tomales Bay and Drakes Estero (DE). *: identical sequences of selected amplified OsHV DNA fragments. Light gray bar: CPCR amplification of non-OsHV DNA
qPCR or cPCR only. qPCR detected OsHV in 17 more animals than did $\mathrm{CPCR}$, including in Manila clams. OsHV was detected in 6 animals with cPCR only, but only when $500 \mathrm{ng}$ of total template DNA was added to the PCR reaction.

The nested OsHV cPCR detected 3 to 3 million copies in all dilutions that were tested in triplicate. Detection of 1 copy of OsHV DNA occurred in 24 of 60 $(40 \%)$ assays suggesting that the lower limit of detection using the copy numbers we employed is 3 copies.

All samples yielded amplifiable DNA as evidenced by the 810 bp product generated from the SSU rDNA control primers (data not shown).

\section{Histology}

Examination of histological sections from selected individuals of all species (identified by PCR to harbor OsHV DNAs), revealed normal tissue and cellular architecture. Cellular changes consistent with cells infected by herpesviruses such as nuclear hypertrophy or the presence of Cowdry type A inclusion bodies were not observed.

\section{Sequences of PCR-amplified OsHV fragments}

Sequence analysis of selected OsHV cPCR products from each species of oyster indicated that the amplified fragments were identical to one another (100\%), and to previously reported OsHV sequences described from California (Friedman et al. 2005). However, sequence analysis of cPCR products from Mediterranean mussels showed anomalous sequences that did not match any previously reported DNA sequences in GenBank, and those mussels were not considered to be infected by or associated with OsHV. In contrast, sequence analysis of qPCR products from Mediterranean mussels and Manila clams were identical $(100 \%)$ to one another and to other previously reported OsHV-1 (GenBank accession no. AY509253.1; Davison et al. 2005) and OsHV sequences (Friedman et al. 2005, Moss et al. 2007).

\section{DISCUSSION}

We developed a sensitive, specific qPCR assay based on a gene present in a single copy in the OsHV genome to detect and quantify viral DNA extracted from bivalve mollusc tis- 


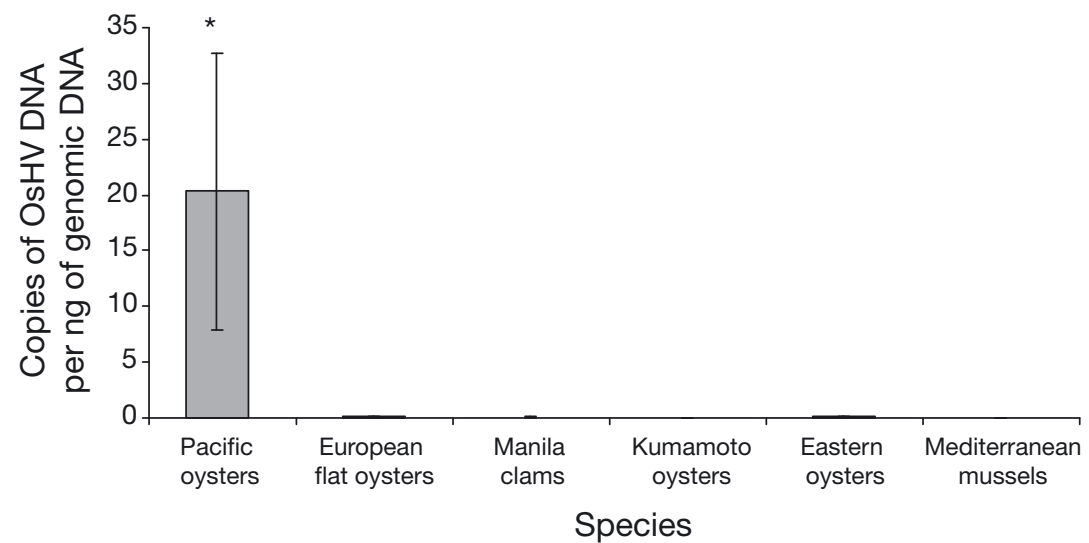

Fig. 4. Copy number per ng of OsHV DNA in Pacific, flat, Kumamoto, and eastern oysters, Manila clams, and Mediterranean mussels (mean \pm SE). Pacific oysters $(*)$ had greater copy numbers than all other species $(\mathrm{p}<0.0001)$, and no other differences among species were detected $(\mathrm{p}>0.05)$

sues, and to better understand host-parasite dynamics in this system. Using this qPCR assay, we detected and quantified OsHV viral loads, a proxy for intensity of viral presence or infection, in Pacific oysters, European flat oysters, Kumamoto oysters, eastern oysters, Manila clams, and Mediterranean mussels collected in TB, California, shortly after reports of mass mortalities of Pacific oysters in the sampled embayment. Local shellfish growers have not reported any mortalities in bivalves other than the Pacific oyster reared in TB (J. Finger, Hog Island Oyster Company, pers. comm.). Despite a lack of reported losses, gill and mantle tissues of individuals of each of the other species examined had cPCR and/or qPCR evidence of OsHV presence, except the native Olympia oyster (cPCR analysis only). Although still considered low level infections, significantly higher OsHV copy numbers were detected in Pacific oysters than in all other species assessed, including the European flat oysters examined. This latter species, based on $\mathrm{CPCR}$, had the highest OsHV prevalence (78.57\%), while Pacific oysters had much lower prevalences of OsHV DNA (46.30 and $47.22 \%$ at $\mathrm{TB}$ and $\mathrm{DE}$, respectively) further demonstrating that $\mathrm{CPCR}$ does not adequately describe the hostOsHV interactions. cPCR prevalences observed in Pacific oysters in the present study are similar to those observed previously in TB (Burge et al. 2006). Given the low number of European flat oysters examined, additional samples are needed to further characterize OsHV presence in this species.

Sequence analysis of selected CPCR or qPCR products confirm OsHV DNA in all species tested except Olympia oysters (cPCR negative, no sequence analysis) in TB. qPCR sequence analysis revealed perfect alignment with OsHV-1 (Davison et al. 2005), OsHV previously detected in California (Friedman et al. 2005), and OsHV detected in South Korea, Japan, and China (Moss et al. 2007) indicating good specificity of this assay where genetic information is available for OsHVs. We describe the first detection and sequence confirmation of OsHV in a new embayment (Pacific oyster in DE) and in 2 new species in TB, Mediterranean mussels and Eastern oysters; herpes-like viruses in bivalves were first described using histology

Table 3. Comparison of presence/absence PCR methods to detect OsHV in a subset of samples of bivalves collected in Tomales Bay; Crassostrea gigas, C. sikamea, C. virginica, Ostrea edulis, and Venerupis phillipinarum were collected on August 27, 2003, and Mytilus galloprovincialis on September 24, 2003. Samples were tested with conventional PCR (cPCR) using $1 \mu$ l ( 50 ng; amount of template added to PCR reaction) and a total of $500 \mathrm{ng}$ of genomic DNA, and with quantitative PCR (qPCR) using $2 \mu \mathrm{l}$ genomic DNA (melt curve analysis for each sample indicates an OsHV amplicon). Column labels: cPCR (qPCR) = number of samples for each species containing OsHV DNA based on cPCR (qPCR), and the total for each column; Total PCR = total number of samples for each species containing OsHV DNA; $\mathrm{CPCR}$ only = number of samples where OsHV DNA was detected only with CPCR (with $1 \mu \mathrm{l}$ or $500 \mathrm{ng}$ of genomic DNA); qPCR only = number of samples where OsHV DNA was detected only with qPCR $(2 \mu \mathrm{l})$. Sequence confirmation for CPCR was achieved in a subset of samples from each species except Mediterranean mussels; sequence confirmation for qPCR was achieved in Mediterranean mussels

\begin{tabular}{|c|c|c|c|c|c|c|c|c|}
\hline \multirow[t]{2}{*}{ Species } & \multirow{2}{*}{$1 \mu \mathrm{l}$} & \multirow{2}{*}{$\begin{array}{r}\quad \mathrm{CPCR} \\
500 \mathrm{ng}\end{array}$} & \multirow{2}{*}{$\overline{\text { Total }}$} & \multirow{2}{*}{$\begin{array}{l}\text { qPCR } \\
2 \mu \mathrm{l}\end{array}$} & \multirow[t]{2}{*}{ Total PCR } & \multicolumn{2}{|c|}{ - $\mathrm{cPCR}$ only - } & \multirow{2}{*}{$\begin{array}{c}\text { qPCR only } \\
2 \mu \mathrm{l}\end{array}$} \\
\hline & & & & & & $1 \mu \mathrm{l}$ & $500 \mathrm{ng}$ & \\
\hline Pacific oyster & 7 & 10 & 10 & 9 & 12 & 0 & 3 & 2 \\
\hline Flat oyster & 11 & 10 & 11 & 10 & 11 & 0 & 1 & 0 \\
\hline Manila clams & 0 & 0 & 0 & 3 & 3 & 0 & 0 & 3 \\
\hline Kumamoto oyster & 4 & 5 & 5 & 13 & 13 & 0 & 0 & 7 \\
\hline Eastern oyster & 3 & 6 & 8 & 8 & 9 & 0 & 1 & 2 \\
\hline Mediterranean mussel & 1 & 2 & 2 & 4 & 4 & 0 & 1 & 3 \\
\hline Total & 26 & 33 & 36 & 47 & 52 & 0 & 6 & 17 \\
\hline
\end{tabular}


and transmission electron microscopy (TEM) from eastern oysters (Farley et al. 1972) but whether this herpes-like virus was OsHV is unknown as no sequence confirmation has been made to date.

Based on plasmid dilution curves, both the qPCR and the nested CPCR assay are highly sensitive; qPCR detected 10 copies $100 \%$ of the time, 3 copies $>95 \%$ of the time, and 1 copy $50 \%$ of the time; whereas the nested cPCR detected 1 copy $40 \%$ of the time. To optimally compare CPCR and qPCR, samples should be run simultaneously. In the present work, samples were frozen and thawed between CPCR and qPCR assays. Taken together, the data suggest that both qPCR and CPCR are sensitive in detecting OsHV. However, qPCR appears to be a more sensitive test for OsHV presence as this test detected OsHV DNA in more samples than did CPCR (47:34), despite the fact that the qPCR was run on samples that were frozen for several years. These results are consistent with expectations as qPCR is frequently more sensitive than cPCR (e.g. Pepin et al. 2008). The qPCR assay also detected OsHV DNA in 2 additional species (Mediterranean mussels and Manila clams) not demonstrated by $\mathrm{CPCR}_{\text {, and pro- }}$ vided quantitative data on OsHV abundances in tested samples. Quantitative data for OsHV is limited and the type of data collected herein may be especially important for further study of this pathogen, which is not culturable and lacks histological signs of infection in juvenile and adult oysters (Friedman et al. 2005, Burge et al. 2006). For example, transmission of the virus from infected adult and seed bivalves to naïve seed bivalves has been especially difficult and qPCR may facilitate assessment of successful viral replication in such transmission studies.

OsHV viral loads have been shown to vary among samples. Sauvage et al. (2009) compared qPCR copy number in living $\left(2.5 \times 10^{2}\right.$ to $1.1 \times 10^{8}$ copies $\left.\mathrm{mg}^{-1}\right)$, dead $\left(2.04 \times 10^{6}\right.$ to $\left.4.84 \times 10^{8}\right)$ and surviving individuals $\left(1.02 \times 10^{2}\right.$ to $\left.3.34 \times 10^{2}\right)$ in full-sib Pacific oyster families during an OsHV epidemic in France. In Sauvage et al.'s (2009) assessment, copy number was significantly lower in animals surviving to the end of the epidemic compared to dead and living individuals collected during the epidemic. Our qPCR data revealed the presence of low OsHV copy numbers in tissues of all tested species for which OsHV DNA was amplified and that a significant difference was found in viral load between Pacific oysters and all other species tested. Although only a limited number of samples were analyzed with $\mathrm{qPCR}$, it is likely that testing more individuals using qPCR would yield similarly low viral loads; the nested CPCR assay is very sensitive and would have identified OsHV in most infected individuals. This is the first published study using qPCR to assess diseases of molluscs from TB, and only included animals that survived an OsHV epidemic, which resulted in reported losses only in Pacific oysters. Direct copy number comparisons cannot be made between the experiment by Sauvage et al. (2009) and the present study, since copy number was normalized with $\mathrm{mg}$ of tissue in the former report; we normalized to ng of total DNA.

Detection of OsHV with cPCR or qPCR may not always equate to mortality as OsHV has been detected in individuals deemed 'healthy' by histology (3.8\% of those tested; Barbosa-Solomieu et al. 2004), where no known mortality has occurred (Pepin et al. 2008), or in stocks or families where low levels of mortality have occurred (Burge et al. 2006, Sauvage et al. 2009). Mortality of oysters where OsHV is present may vary among stocks or families of oysters procured from different geographic regions (Burge et al. 2006, 2007, da Silva et al. 2008), or even half- or full-sib families (da Silva et al. 2008, Sauvage et al. 2009), which suggests that inherited resistance to OsHV may affect pathological outcomes of exposure or infection. Determination of whether a trend or relationship exists among viral load and histological changes and/or mortality would help further characterize the oysterOsHV relationship.

Detection of OsHV with sensitive assays such as CPCR and qPCR does not imply an active virus infection or a true infection: it can only yield presence (CPCR) or presence and quantity (qPCR) data for OsHV DNA. Indeed, one can detect OsHV in any of the following stages: abortive (not true infections), latent (productive but silent infection), or active (productive with viral assembly) within tissue samples. To confirm a true OsHV infection in tissues where cellular or tissue changes are absent or rare by histological examination, assays such the OsHV-specific in situ hybridization (ISH) (Lipart \& Renault 2002) or immunohistochemistry used by Arzul et al. (2002) are necessary. However, as illustrated by several studies, ISH confirmation of infection is limited by a need of adequate copy numbers of the target gene for visualization of a positive signal (Barbosa-Solomieu et al. 2004, Haffar \& Gilbride 2010). Detection of OsHV by PCR revealed the presence of target DNA in 8.9 to $41.1 \%$ of the samples examined relative to $12.1 \%$ positive reactions by ISH (Barbosa-Solomieu et al. 2004). In addition, those authors only observed $\sim 3 \%$ of the samples positive by ISH when over $50 \%$ of the samples were also PCR positive. In one group, no ISH evidence of OsHV presence was observed, despite the fact that $73.3 \%$ of the animals showed PCR evidence of OsHV presence. As in the present study, many of the bivalves examined by Barbosa-Solomieu et al. (2004) were not collected during a mortality event and had been archived for about 10 yr. In another study, Haffar \& Gilbride (2010) 
revealed a limit of detection of their qPCR assay as 150 copies, which was below the detection limit of their fluorescent ISH tests. Taken together, these date suggest that most of our samples, which contained $<50$ gene copies per PCR reaction (except for 3 Pacific oyster samples), are not good candidates for ISH. Future studies in which bivalves are collected during a mortality event, when viral copy numbers are elevated, should be subjected to ISH analysis to determine if these animals are infected with OsHV. Further, active OsHV invection cannot be inferred from any currently available molecular method and since continuous cell lines from bivalve molluscs are unavailable, active virus replication cannot be quantified using standard virological methods such as plaque assays. The use of qPCR to study OsHV is relatively new, and may eventually provide data on how much or little OsHV DNA leads to mortality. A method such as reverse transcriptase qPCR targeting a gene only expressed during active infection, would be useful for quantifying infection status in order to better understand OsHV pathogenesis and disease transmission including both host reservoirs and spread of the virus.

Histological analysis revealed that OsHV PCR-positive bivalves collected during this study lacked tissue abnormalities in cellular and tissue architecture, even in those with the highest OsHV copy numbers observed in the present study. This is not the first report of OsHV detection in host tissues that lack identifiable pathological effects and/or mortalities. In France, Barbosa-Solomieu et al. (2004) describe OsHV detection $(69.6 \%)$ using cPCR (C9/C10 primers) in adult Crassostrea gigas that were previously deemed as healthy, and Moss et al. (2007) detected OsHV using cPCR (same methods herein) in multiple Crassostrea spp. in Asia (life stage not listed). Histological changes consistent with herpesvirus infections have been described in adult French scallops Pecten maximus (Arzul et al. 2001a) and in Chilean flat oysters Ostrea angasi (Hine \& Thorne 1997) where mortalities associated with OsHV were not documented.

Although published records documenting relative survival of all bivalves reared in TB are lacking, shellfish farmers would note high losses of any species that would affect their business. However, members of species that become infected by OsHV but do not suffer mortalities may serve as reservoirs of infection, particularly when reared in close proximity to susceptible animals. Thus, interspecies transmission could enhance OsHV transmission and epidemic dynamics in TB. In addition, the presence in TB of the lethal protistan pathogen Bonamia ostreae, which infects Ostrea edulis (Friedman et al. 1989), may mask OsHVinduced losses among European flat oysters. Interestingly, the Pacific oysters in DE had a similar OsHV prevalence based on $\mathrm{CPCR}$ as those reared in $\mathrm{TB}$, yet no other commercially cultured shellfish species is reared in DE. This raises the possibility that a non-cultured host animal may also host OsHV, or that survivors of past OsHV epidemics may serve as a sufficient reservoir for OsHV transmission to naïve seed planted annually. Non-cultured host animals such as the rotifer Brachionus urceus Linnaeus, 1758 (Zhang et al. 2006) and 3 crab species (Sesarma sp., Scylla serrata, and Uca pugilator) (Kanchanaphum et al. 1998) have been determined to serve as infection reservoirs of white spot syndrome virus (WSSV), another viral pathogen affecting marine invertebrate hosts, illustrating that marine viruses may have broad host ranges thereby affecting transmission dynamics.

In conclusion, understanding the potential for host reservoirs, interspecies transmission, and host-parasite dynamics leading to an epidemic is crucial for successful culture of Pacific oysters in areas where OsHV is endemic. To better understand each species as a potential reservoir, both field and laboratory studies quantifying mortality, copy number, infection status (i.e. active versus abortive or latent infections), and host response to the virus in bivalves at different known life stage (seed versus adults) over time are needed. Additionally, testing other non-cultured bivalves or other organisms may be necessary, in order to prevent an inadvertent spread of this pathogen.

Acknowledgements. We are grateful to the shellfish growers in Tomales Bay and Drakes Estero for providing samples and continued support. We thank C. Dungan, B. Vadopalas, and V. Lowe for their editorial comments. This research was funded, in part, by a grant from the Oyster Disease Research Program, National Oceanic and Atmospheric Administration, US Department of Commerce, under grant no. NA04OAR4170032 and NA16RG1668. The views expressed herein are those of the authors and do not necessarily reflect the views of NOAA or any of its sub-agencies. The US government is authorized to reproduce and distribute for governmental purposes.

\section{LITERATURE CITED}

Altschul SF, Gish W, Miller W, Myers EW, Lipman DJ (1990) Basic local alignment search tool. J Mol Biol 215:403-410 Arzul I, Nicolas JL, Davison AJ, Renault T (2001a) French scallops: a new host for ostreid Herpesvirus-1. Virology 290:342-349

Arzul I, Renault T, Lipart C, Davison AJ (2001b) Evidence for interspecies transmission of oyster herpesvirus in marine bivalves. J Gen Virol 82:865-870

Arzul I, Renault T, Thebault A, Gerard A (2002) Detection of oyster herpesvirus DNA and proteins in asymptomatic Crassostrea gigas adults. Virus Res 84:151-160

> Barbosa-Solomieu V, Miossec L, Vasquez-Juarez R, AscencioValle F, Renault T (2004) Diagnosis of ostreid herpesvirus 1 in fixed paraffin-embedded archival samples using PCR and in situ hybridization. J Virol Methods 119:65-72 
Batista FM, Arzul I, Pepin JF, Ruano F, Friedman CS, Boudry P, Renault T (2007) Detection of ostreid herpesvirus 1 DNA by PCR in bivalve molluscs: a critical review. J Virol Methods 139:1-11

Burge CA, Griffin FJ, Friedman CS (2006) Mortality and herpesvirus infections of the Pacific oyster Crassostrea gigas in Tomales Bay, California, USA. Dis Aquat Org 72:31-43

Burge CA, Judah LR, Conquest LL, Griffin FJ and others (2007) Summer seed mortality of the Pacific oyster, Crassostrea gigas Thunberg, grown in Tomales Bay, California, USA: the influence of oyster stock, planting time, pathogens, and environmental stressors. J Shellfish Res 26:163-172

Cherr GN, Friedman CS (1998) Investigation of a mass mortality of pacific oysters, Crassostrea gigas, in Tomales Bay, California. In: California Sea Grant Report of Completed Projects 1994-1997 No. R-044. California Sea Grant College System, La Jolla, CA, p 167-172

da Silva PM, Renault T, Fuentes J, Villalba A (2008) Herpesvirus infection in European flat oysters Ostrea edulis from brood stocks of various geographic origins and grown in Galicia (NW Spain). Dis Aquat Org 78:181-188

Davison AJ, Trus BL, Cheng N, Steven AC and others (2005) A novel class of herpesvirus with bivalve hosts. J Gen Virol 86:41-53

Farley CA, Banfield WG, Foster WS (1972) Oyster herpestype virus. Science 178:759-760

Friedman CS, McDowell T, Groff JM, Hollibaugh JT, Manzer D, Hedrick RP (1989) Presence of Bonamia ostreae among populations of the European flat oyster, Ostrea edulis Linne, in California, USA. J Shellfish Res 8:133-137

Friedman CS, Estes RM, Stokes NA, Burge CA and others (2005) herpesvirus in juvenile Pacific oysters Crassostrea gigas from Tomales Bay, California, coincides with summer mortality episodes. Dis Aquat Org 63:33-41

Haffar M, Gilbride KA (2010) The utility and application of real-time PCR and FISH in the detection of single copy gene targets in Escherichia coli O157:H7 and Salmonella typhimurium. Can J Microbiol 56:254-262

Hine PM, Thorne T (1997) Replication of herpes-like viruses in haemocytes of adult flat oysters Ostrea angasi: an ultrastructural study. Dis Aquat Org 29:189-196

Hine PM, Wesney B, Hay BE (1992) Herpesviruses associated with mortalities among hatchery-reared larval Pacific oysters Crassostrea gigas. Dis Aquat Org 12:135-142

Kanchanaphum P, Wongteerasupaya C, Sitidilokratana N, Boonsaeng $V$ and others (1998) Experimental transmission of White Spot Syndrome Virus (WSSV) from crabs to shrimp Penaeus monodon. Dis Aquat Org 34:1-7

Editorial responsibility: Eugene Burreson, Gloucester Point, Virginia, USA
Le Roux F, Audemard C, Bernaud A, Berthe F (1999) DNA probes as potential tools for the detection of Marteilia refringes. Mar Biotechnol 1:588-597

> Lipart C, Renault T (2002) Herpes-like virus detection in infected Crassostrea gigas spat using DIG-labelled probes. J Virol Methods 101:1-10

Luna LG (ed)(1968) Manual of histologic staining methods of the Armed Forces Institute of Pathology, 3rd edn. McGraw-Hill, New York, NY

Moss JA, Burreson EM, Cordes JF, Cungan CF and others (2007) Pathogens in Crassostrea ariakensis and other Asian oyster species: implications for non-native oyster introduction in Chesapeake Bay. Dis Aquat Org 77: 207-233

Nicolas JL, Comps M, Cochennec N (1992) Herpes-like virus infecting Pacific oyster larvae, Crassostrea gigas. Bull Eur Assoc Fish Pathol 12:11-13

Pepin JF, Riou A, Renault T (2008) Rapid and sensitive detection ostreid herpesvirus 1 in samples by real-time PCR. J Virol Methods 149:269-276

Renault T, Le Deuff RM, Chollet B, Cochennec N, Gérard A (2000a) Concomitant herpes-like infections in hatcheryreared larvae and nursery-cultured spat Crassostrea gigas and Ostrea edulis. Dis Aquat Org 42:173-183

Renault T, Le Deuff RM, Lipart C, Delsert D (2000b) Development of a PCR procedure for the detection of a herpes-like virus infecting oysters in France. J Virol Methods 88:41-50

> Renault T, Arzul I, Lipart C (2004) Development and use of an internal standard for oyster herpesvirus 1 detection by PCR. J Virol Methods 121:17-23

Sauvage C, Pepin JF, Lapegue S, Boudry P, Renault T (2009) Ostreid herpesvirus 1 infection in families of the Pacific oyster, Crassostrea gigas, during a summer mortality outbreak: differences in viral DNA detection and quantification using real-time PCR. Virus Res 142:181-187

Shaw BL, Battle HI (1957) The gross and microscopic anatomy of the digestive tract of the oyster, Crassostrea virginica (Gmelin). Can J Zool 35:325-347

Wright P, Jacobson R (2009) Principles and methods of validation of diagnostic assays for infectious diseases. In: Manual of diagnostic tests for aquatic animals 2009. OIE (World Organisation for Animal Health), Paris, p 10-23. Available at www.oie.int/fileadmin/home/eng/health standards/aahm/2010/1.1.2_ VALID.pdf

Zar JH (1999) Biostatistical analysis. Prentice Hall, Upper Saddle River, NJ

Zhang JS, Dong SL, Tian XL, Dong YW, Liu XY, Yan DC (2006) Studies on the rotifer (Brachionus urceus Linnaeus, 1758) as a vector in white spot syndrome virus (WSSV) transmission. Aquaculture 261:1181-1185

Submitted: December 22, 2009; Accepted: November 24, 2010 Proofs received from author(s): March 15, 2011 